\title{
New kimberlite discoveries in Kuusamo, northern Finland
}

\author{
Hugh E. O'Brien ${ }^{1}$ and Johan Bradley ${ }^{2}$ \\ ${ }^{1}$ Geological Survey of Finland, P.O. Box 96, FI-02151, Espoo, Finland \\ ${ }^{2}$ Sunrise Diamonds plc, Sunrise House, Hulley Road, Macclesfield, Cheshire, SK10 2LP, United Kingdom
}

A third kimberlite province in Finland has recently been discovered and is represented by seven kimberlite bodies in four different localities within a $20 \mathrm{~km}$ radius south of Kuusamo, adding to the provinces at KaaviKuopio and Lentiira-Kuhmo (Fig. 1). The kimberlites were discovered by Sunrise Diamonds plc as part of their ongoing diamond exploration program in Finland.

Six of the Kuusamo discoveries are classified as Group I kimberlites and the 7th as a Group II. Hypabyssal kimberlites Kattaisenvaara (KV), Kalettomanpuro (KP) and Lampi share many petrographic features. They consist of serpentinized olivine macrocrysts and phenocrysts in a fine-grained matrix composed of microphenocrysts of phlogopite, perovskite, apatite and spinel with late stage carbonate and serpentine filling grain interstices (Fig. 2).

The other three Group I kimberlites, named 47, 45 and 45 South, occur within several hundred meters of each other, at the Kasma locality. Kimberlite 45 contains both hypabyssal and diatreme-facies types, whereas only diatreme material was recovered from 47 . The tuffisitic kimberlite in these small pipes contains abundant pelletal lapilli (Fig. 3) and some samples from 45 appear to be composed dominantly of lapilli. Mineralogically these Kasma Group I kimberlites are distinct from KV-KP-Lampi in that they are very perovskite-rich and phlogopite is rare to absent. The seventh kimberlite, an indicator mineral-rich Group II kimberlite dike intersected at Kalettomanpuro, appears to be another member of the $1.2 \mathrm{Ga}$ phlogopite-rich dike rocks described from the Lentiira-KuhmoKostomuksha area.

Mica compositions of the KV-KP kimberlites are highly Al- and Ba-enriched kinoshitalites, typical of Group I kimberlite microphenocrysts, with rare tetraferriphlogopite rims detected on some $\mathrm{KV}$ grains. Lampi kimberlite, on the other hand, has mica that is Ba-rich, yet with only moderate $\mathrm{Al}_{2} \mathrm{O}_{3}$ and $\mathrm{TiO}_{2}(10-14$ wt\% \& 2-4 wt\%, respectively); mica compositions that extend from the Group I field through the Group II compositional field. Finally, the zoning patterns from high $\mathrm{Al}_{2} \mathrm{O}_{3}$ toward lower $\mathrm{Al}_{2} \mathrm{O} 3$ are coupled with decreasing $\mathrm{TiO}_{2}$ (Fig. 4), exactly the opposite of what is seen in ultramafic lamprophyre mica zonation patterns.

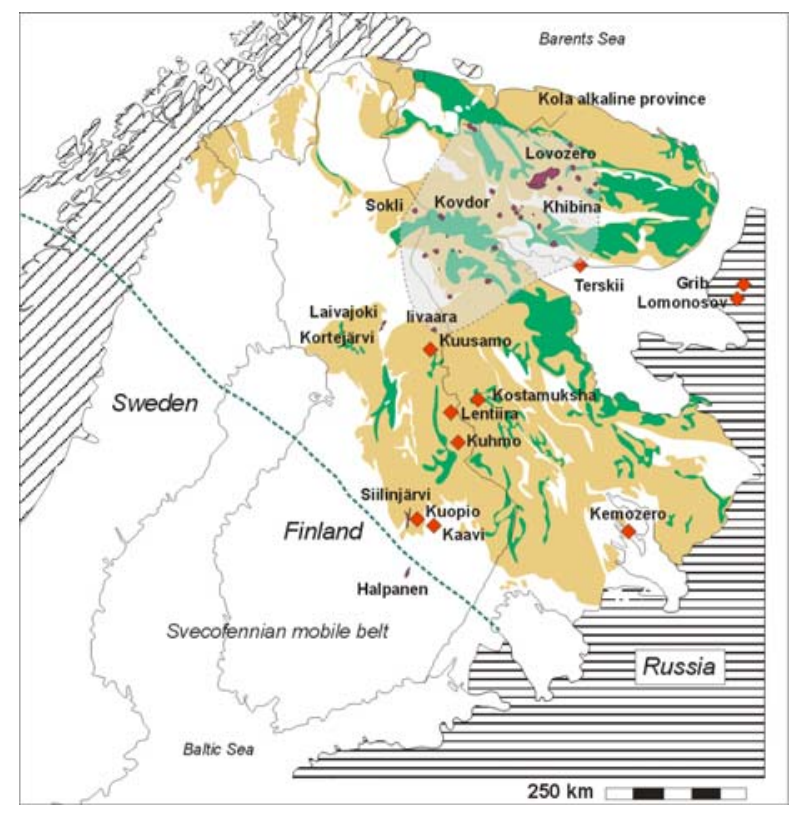

Fig. 1. Kimberlite localities in the Karelian-Kola-Kuloi supercraton (red diamonds) and other selected alkaline rocks localities (purple blobs). Dashed line marks the SW edge of the craton. Generalised geology is modified after Gaál and Gorbatschev (1987).

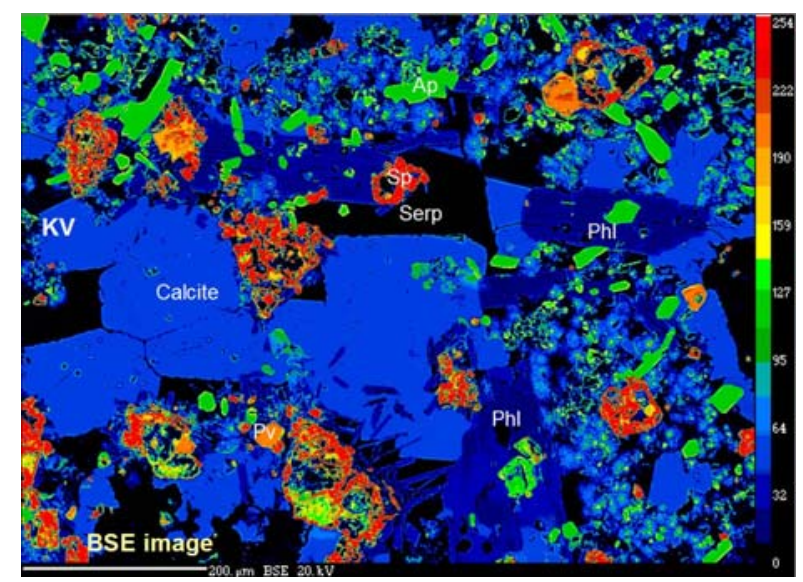

Fig. 2. BSE image of the matrix from the $\mathrm{KV}$ kimberlite. Main minerals are Ba-Al-rich kinoshitalite mica (dk. blue), calcite (blue), serpentine (black), apatite (green), perovskite (orange) and magnetite (red). Bar at bottom of image is 200 micrometers. 


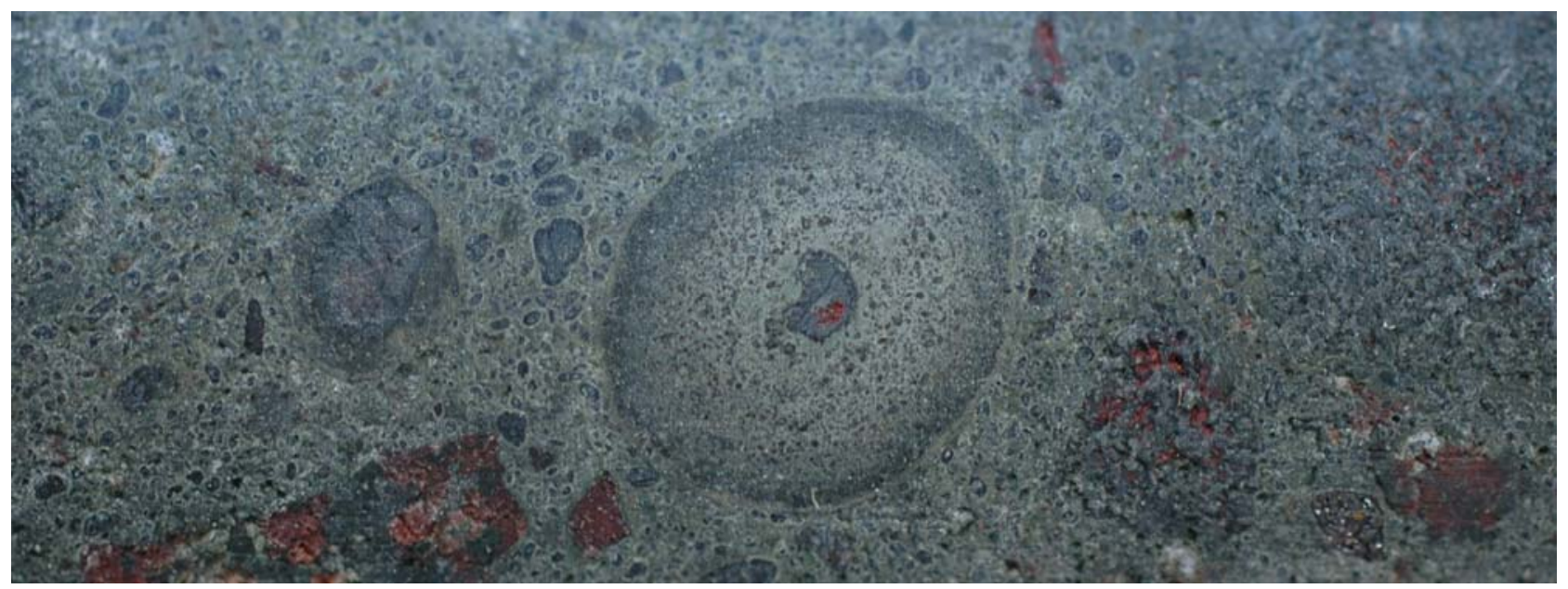

Fig. 3. Close-up of drill core from Kasma kimberlite 47 showing an example of well-developed pelletal lapilli common to this kimberlite and interpreted to indicate diatreme facies. Lapillus is about $1 \mathrm{~cm}$ in diameter.

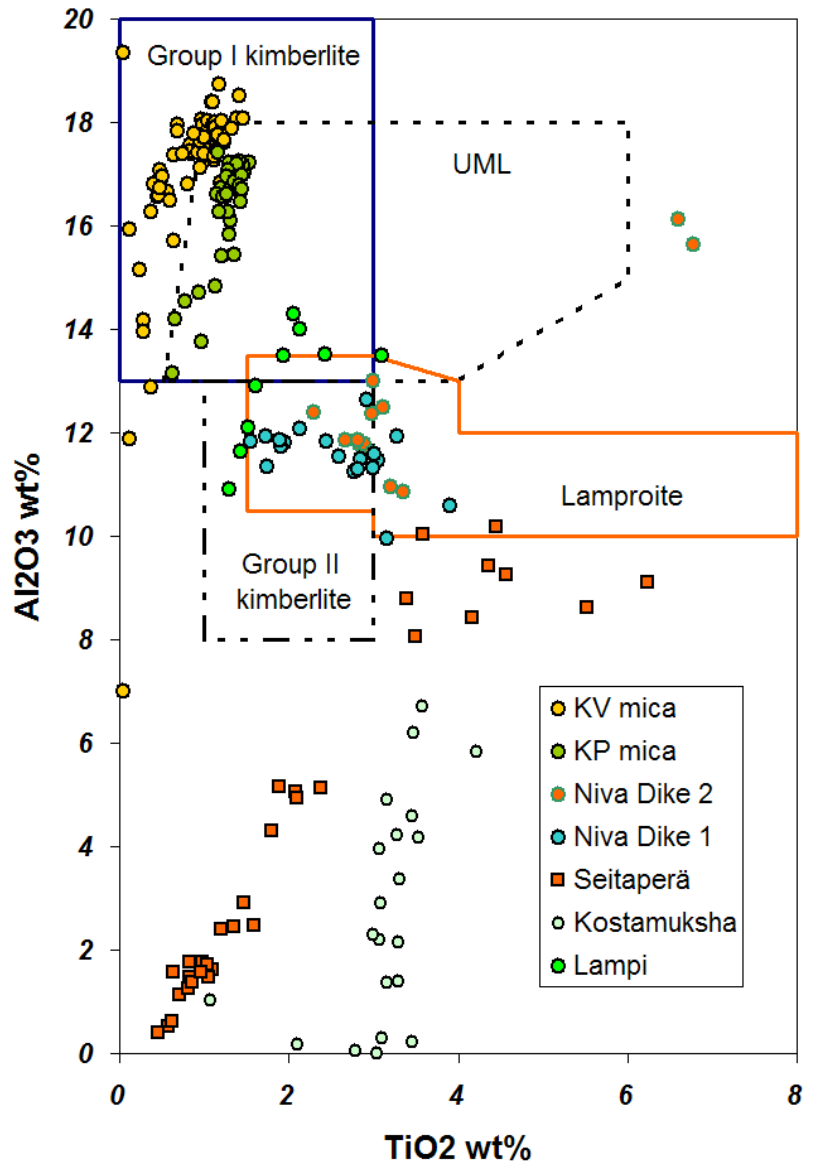

Fig. 4. Mica compositions from Kalettomanpuro (KP) and Kattaisenvaara (KV) Group I kimberlite micas plotted in $\mathrm{TiO}_{2}$ vs $\mathrm{Al}_{2} \mathrm{O}_{3}$ along with data from Lampi kimberlite. Other mica grain compositions plotted are from Group II kimberlites from Kuhmo, including Niva Dikes, Seitaperä and Kostamuksha. All of the KP and KV points plot directly in the Group I kimberlite compositional field, although there is some overlap with the ultramafic lamprophyre (UML) field. Compositional fields after Mitchell, 1995.
The KV-KP-Lampi kimberlites are moderately to highly magnetic, and this is directly related to the relatively high modal abundance of magnetite. The Kasma kimberlites, which contain less magnetite, are consequently less magnetic, but nevertheless produced distinct anomalies in a ground magnetic survey against a relatively nonmagnetic baseline (Fig. 5).

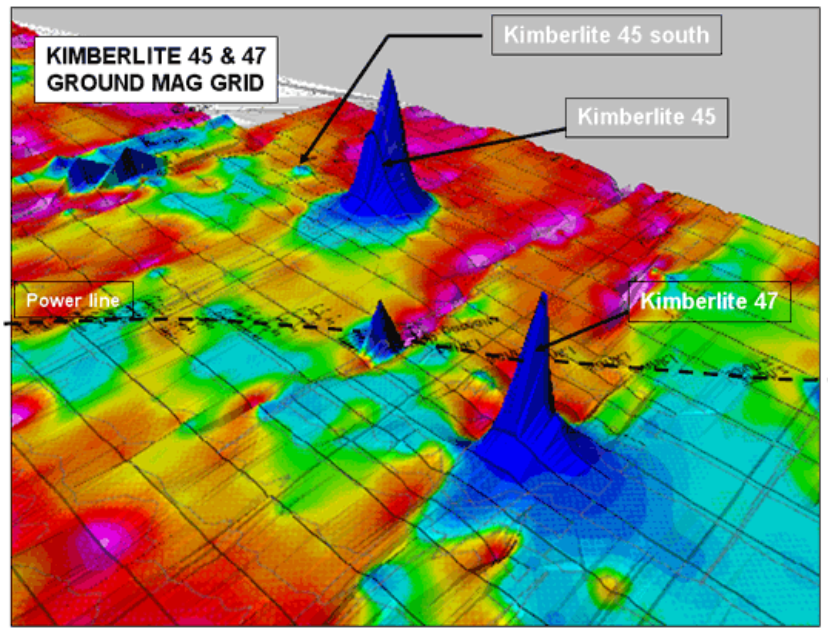

Fig. 5 Results of a ground magnetic survey over the Kasma kimberlites conducted by GTK for Sunrise Diamonds plc.

Major element data confirm the relatively evolved nature of the KV-KP-Lampi kimberlites. Plots such as $\mathrm{Fe}_{2} \mathrm{O}_{3}-\mathrm{SiO}_{2}$ (Fig. 6) and $\mathrm{CaO}-\mathrm{MgO}$ (not shown) indicate that the Kuusamo Gp I kimberlites plot slightly outside the field for typical Gp I rocks, with a vector toward the magnetite and perovskite-enriched partial cumulates from the Benfontein sill where extreme $\mathrm{Fe}_{2} \mathrm{O}_{3}$ contents reflect accumulation of significant magnetite. Diamondiferous kimberlites (for example Zolotitsa, Finsch, some Kaavi-Kuopio samples), are in fact relatively $\mathrm{SiO}_{2}$-rich, with ca. 40$45 \mathrm{wt} \% \mathrm{SiO}_{2}$. Despite their evolved nature, microdiamonds have been recovered from kimberlites $\mathrm{KV}$ and Lampi. Microdiamonds have also been recovered 
from the Kasma locality (kimberlite 45) but comparative chemical analyses have not been made due to the lack of magmatic kimberlite at this locality.

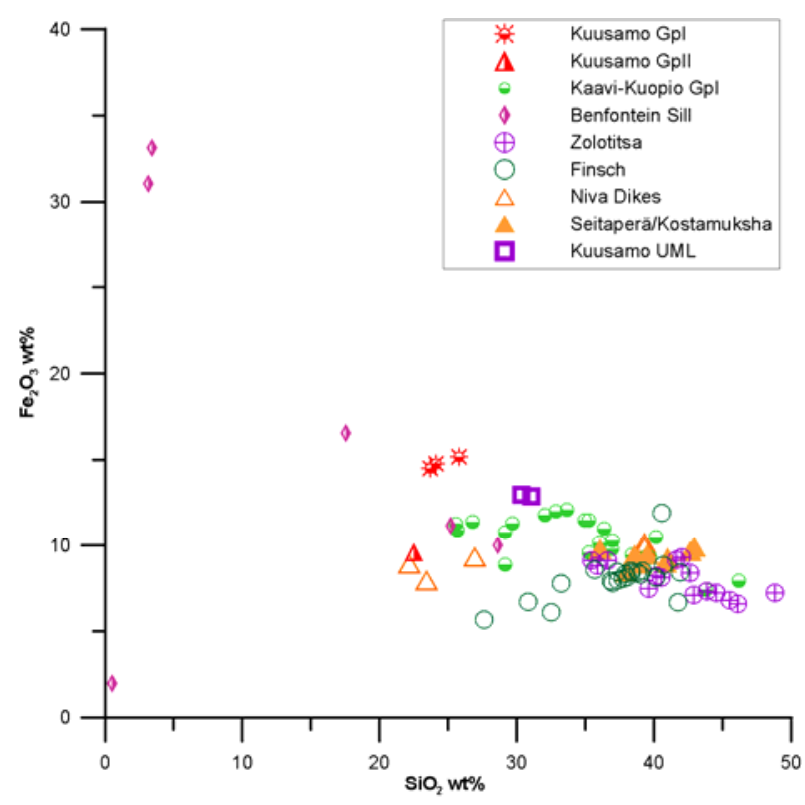

Fig. 6. $\mathrm{Fe}_{2} \mathrm{O}_{3}$ wt\% versus $\mathrm{SiO}_{2} \mathrm{wt} \%$ for selected kimberlites and kimberlitic rocks.

A Zr-Nb discriminant diagram (Taylor et al., 1994) devised to separate various types of kimberlites and allied rocks is shown in Fig. 7. For the KV-KP-Lampi rocks the diagram gives mixed results, in that the Group I kimberlites are properly positioned, but the Group II from Kalettomanpuro is identified also as

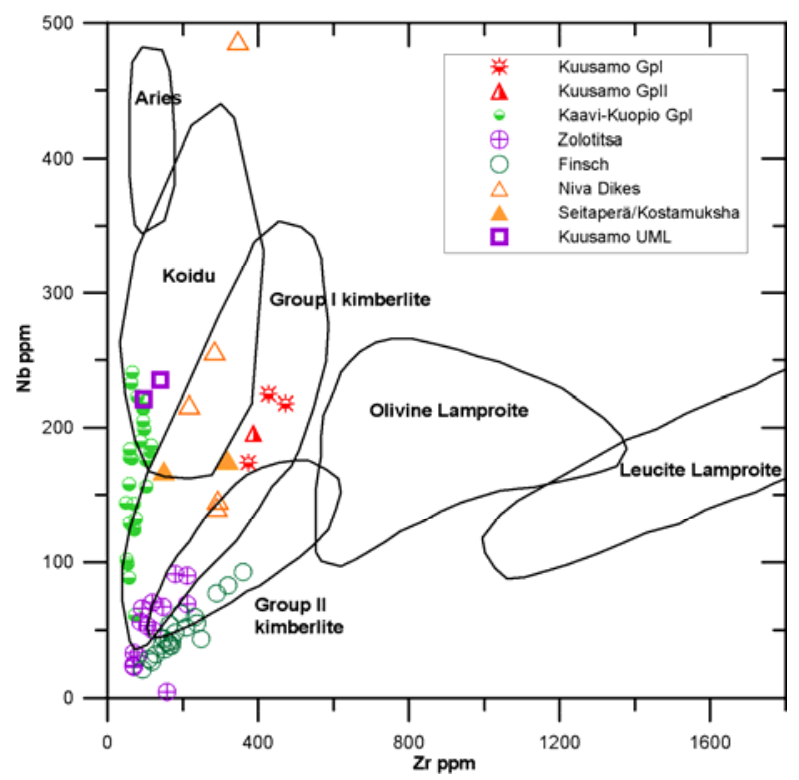

Fig. 7. Nb-Zr discriminant plot for kimberlites and related rocks. Fields are after Taylor et al., 1994.
Group I, which it clearly is not. In fact all of the Group II kimberlite-like rocks from Lentiira and Kostamuksha also plot within the Group I field on this diagram, pointing to the unique attributes of these Karelian craton lithospheric mantle melts (see O’Brien and Tyni, 1999 for discussion).

Although the ages of the Kuusamo kimberlites are still to be fully resolved, new U-Pb work on two perovskite fractions from one sample each of the KP and KV kimberlites gave weighted mean ${ }^{206} \mathrm{~Pb} /{ }^{238} \mathrm{U}$ ages of 759 $\pm 15 \mathrm{Ma}$ and $756.8 \pm 2.1 \mathrm{Ma}$, respectively. The fact that fractions of large blocky perovskite grains and small euhderal grains from each sample gave similar results strongly suggests that these are the crystallization ages of the KP and KV kimberlites. The fact that these kimberlites have the same age within error is in accordance with the similarity of the mineralogical, whole rock, and magnetic properties of these rocks, and strongly suggests that these kimberlites are cogenetic. Testing if the Kasma kimberlites are also of this same age should be relatively straightforward due to their perovskite-rich nature.

The Kuusamo kimberlites mark the third known kimberlite province in Finland, and mark a previously unknown period of kimberlite activity in the Karelian subcraton, emphasizing the potential of even more undiscovered kimberlites in the region.

\section{References}

Gaál, G., Gorbatschev, R., 1987. An outline of the Precambrian evolution of the Baltic Shield.Precambrian Research 35, 15-52.

Mitchell R.H., 1995. Kimberlites, orangeites, and related rocks. Plenum, New York, 410 pp.

O’Brien, H.E., Tyni, M., 1999. Mineralogy and geochemistry of kimberlites and related rocks from Finland. In: Gurney, J.J., Gurney, J.L., Pascoe, M.D. and Richardson, S.H. (Eds.), Proceedings of the 7th International Kimberlite Conference, 625-636.

Taylor W.R., Tompkins L.A., Haggerty S.E., 1994. Comparative geochemistry of West African kimberlites: Evidence for a micaceous kimberlite endmember of sublithospheric origin. Geochimica et Cosmochimica Acta 58, pp. 4017-4037. 